\title{
Interaction of Chlamydia trachomatis with Human Genital Epithelium in Culture
}

\author{
By DAVID R. MOORMAN, ${ }^{2}$ JOHN W. SIXBEY ${ }^{2}$ AND \\ PRISCILLA B. WYRICK ${ }^{1 *}$ \\ ${ }^{1}$ Department of Microbiology and Immunology, University of North Carolina School of Medicine, \\ Chapel Hill, North Carolina 27514, USA \\ ${ }^{2}$ Division of Infectious Diseases, St Jude Children's Research Hospital, Memphis, \\ Tennessee 38101, USA
}

(Received 14 June 1985 ; revised 17 October 1985)

\begin{abstract}
Primary cultures of human endometrial and ectocervical epithelial cells were examined as a new model system to study genital infection by Chlamydia trachomatis. Initial studies demonstrated that these cells were indeed susceptible to chlamydial infection. Inocula, adjusted to produce inclusions in 50 to $80 \%$ of equivalent numbers of standard McCoy cells, resulted in infection rates of approximately 15 to $30 \%$ for the columnar cells of the endometrium and 5 to $10 \%$ for the squamous cells of the ectocervix. Exposure of cultures to DEAE-dextran and centrifugationassisted inoculation, manipulations reported to enhance infection of $\mathrm{HeLa}$ and McCoy cells, did not alter the number of inclusion-positive genital cells. Addition of cycloheximide to the postinoculation culture medium slightly increased numbers of inclusion-bearing cells while growth of genital cells in hormone-supplemented medium resulted in a variable effect on inclusion development and a significant reduction in the association of radiolabelled organisms with these cells. The basis for the different levels of infection in McCoy versus genital cell cultures was revealed by immunofluorescence analysis of chlamydial association with host cells immediately after inoculation. Chlamydiae failed to adhere to many cells in the genital cell cultures while adherence to McCoy cells was uniform. In addition, the association of radiolabelled $C$. trachomatis was significantly lower with genital cells than with McCoy cells. Finally, culture conditions were defined which markedly inhibited inclusion development without an immediate loss of chlamydial growth potential. This investigation indicates that primary genital cell cultures are susceptible to chlamydial infection and will be valuable for studies on the nature of $C$. trachomatis interactions with natural human target cells.
\end{abstract}

\section{INTRODUCTION}

Chlamydia trachomatis is a bacterium primarily responsible for ocular and genitourinary tract infections of varying severity. In non-trachoma endemic areas the major reservoir of infection is the human genital tract (Schachter \& Dawson, 1978). C. trachomatis is one of the most common and economically significant sexually transmitted disease pathogens, affecting some two to four million people in the USA annually. One of the major deterrants to the investigation of this agent has been the lack of an appropriate model system, the development of which has been hindered by the fact that humans are the natural hosts. The obligate intracellular nature of $C$. trachomatis means that eukaryotic cell cultures must be used for in vitro study of this organism. HeLa cells and McCoy cells have been used in the majority of research investigations designed to elucidate mechanisms which govern chlamydial interactions with host cells. Although these cells lines are sufficiently susceptible to infection to warrant their use for routine isolation of the organism from clinical samples (Gordon \& Quan, 1965; Kuo et al., 1972; Croy et al., 1975),

Abbreviations: EB, elementary body; DMEM, Dulbecco's modified Eagle`s medium; MEM, minimal essential medium. 
neither is representative of normal target epithelium in vivo. Some investigators have used various manipulations with these cell lines to enhance infection, such as pretreatment with the polycation DEAE-dextran (Kuo et al., 1973; Rota \& Nichols, 1973), centrifugation of chlamydial inocula (Darougar et al., 1974) and addition of cycloheximide to the culture medium (Ripa \& Mårdh, 1977). The development of an alternative cell model system, using nontransformed epithelial cells derived from permissive human target tissue, would seem essential in studying selected aspects of $C$. trachomatis pathogenesis.

In recent years, there has been renewed interest in the use of human in vitro cell culture systems for studying the pathogenesis of bacterial and viral disease agents. Hutchinson et al. (1979) used fallopian tube explants to monitor the effect of $C$. trachomatis infection on epithelial ciliary action, in an attempt to describe potential cellular events contributing to infertility. Harrison \& Riggin (1979) reported that human amnion epithelial cell monolayers were as susceptible to $C$. trachomatis infection as McCoy cell cultures treated with 5-iodo 2-deoxyuridine and DEAEdextran.

The purpose of this investigation was to determine if primary cultures of squamous epithelial cells derived from the ectocervix and columnar epithelial cells derived from endometrial glands could serve as models for $C$. trachomatis infection.

\section{METHODS}

Chlamydial strains. A human urogenital isolate of $C$. trachomatis, E/UW-5/Cx, kindly provided by C. C. Kuo and S. P. Wang, University of Washington, Seattle, was used. For one set of experiments a lymphogranuloma venereum strain, $\mathrm{L} 2 / 434 / \mathrm{Bu}$, was used for comparison with $\mathrm{E} / \mathrm{UW}-5 / \mathrm{Cx}$. This strain was donated by the same investigators.

Cell culture media. MEM. Eagle's minimal essential medium (Gibco) supplemented with $10 \%(\mathrm{v} / \mathrm{v})$ heatinactivated foetal bovine serum ( $\Lambda$ FBS: Sterile Systems Inc.), $4.2 \mathrm{~mm}$-sodium bicarbonate, $1.6 \mathrm{~mm}$-glutamine (Eastman Kodak), $0.02 \%$ streptomycin (Pfizer) and $0.01 \%$ kanamycin (Beecham), was used to prepare $C$. trachomatis stock cultures in McCoy cell monolayers.

$M E M / D$-raline. Before infection with chlamydiae, ectocervical cell cultures were maintained in Eagle's MEM with D-valine substituted for L-valine (Gibco) and supplemented with $12 \%$ AFBS, $10 \mathrm{~mm}$-glutamine, $0.02 \%$ streptomycin, $0.01 \%$ kanamycin, $1.25 \mu \mathrm{g}$ amphotericin $\mathrm{B} \mathrm{ml}^{-1}$ (Squibb) and $5 \mu \mathrm{g}$ hydrocortisone 21hemisuccinate $\mathrm{ml}^{-1}$ (Sigma).

DMEM. Endometrial cells were grown in high-glucose Dulbecco's modified Eagle's medium (Gibco) containing $12 \% \wedge \mathrm{FBS}, 0.11 \mathrm{mg}$ sodium pyruvate $\mathrm{ml}^{-1}, 10 \mathrm{mM}$-glutamine, $0.02 \%$ streptomycin, $0.01 \%$ kanamycin, $1.25 \mu \mathrm{g}$ amphotericin $\mathrm{B} \mathrm{ml}^{-1}$ and $4 \mu \mathrm{g}$ insulin $\mathrm{ml}^{-1}$ (Sigma). Unless stated otherwise, DMEM was also used as the culture medium after inoculation of both McCoy and genital cell cultures with $C$. trachomatis.

Growth, harcest and titration of chlamydiae. Chlamydiae for stock cultures were grown in McCoy cell monolayers, according to the methods described by Kuo et al. (1977) and Newhall et al. (1982) in MEM containing $0.5 \mu \mathrm{g}$ cycloheximide $\mathrm{ml}^{-1}$ (Gallard Schlesinger). Infected monolayers were removed from roller bottles $72-96 \mathrm{~h}$ postinoculation, transferred to $100 \mathrm{ml}$ bottles containing sterile glass beads ( $3 \mathrm{~mm}$ diameter) and sonicated for $5 \mathrm{~min}$ in a sonic water bath (Heat Systems, Ultrasonics Inc.). The sonicate was centrifuged at $478 \mathrm{~g}$ for $10 \mathrm{~min}$ at $4^{\circ} \mathrm{C}$ to remove $\mathrm{McC}$ oy cell debris. The supernatants were removed and centrifuged at $10780 \mathrm{~g}$ for $30 \mathrm{~min}$ at $4{ }^{\circ} \mathrm{C}$ to pellet chlamydiae. The resulting crude elementary body (EB) pellets were resuspended in a buffer containing $0.02 \mathrm{M}$ $\mathrm{NaH}_{2} \mathrm{PO}_{4} \cdot \mathrm{H}_{2} \mathrm{O}, 0.02 \mathrm{M}-\mathrm{Na}_{2} \mathrm{HPO}_{+}, 0.02 \mathrm{M}$-sucrose and $5 \mathrm{~mm}$-glutamine per ml distilled water (2SPG) and frozen at $-70^{\circ} \mathrm{C}$ until needed.

For the preparation of radiolabelled organisms, chlamydiae suspended in $5 \mathrm{ml} 2 \mathrm{SPG}$ were adsorbed to the McCoy cell monolayers in $840 \mathrm{~cm}^{2}$ roller bottles for $2 \mathrm{~h}$ at $35^{\circ} \mathrm{C}$. The inoculum was then removed and $100 \mathrm{ml}$ MEM, containing $0.1 \mathrm{mCi}(3.7 \mathrm{MBq})\left[{ }^{3} \mathrm{H}\right]$ uridine (Research Products International Corp.), was added to the culture and incubation was continued for $72-96 \mathrm{~h}$. The chlamydiae were harvested and partially purified as described above. The radiolabelled organisms were then further purified by Percoll (Pharmacia) density gradient centrifugation according to the method of Newhall et al. (1982). Finally, purified EB were washed with 2SPG to remove the Percoll, sonicated with a microtip probe (Heat Systems, Ultrasonics Inc.) at $40 \mathrm{~Hz}$ for 90 s to break up EB aggregates, resuspended to a particle count of $1 \times 10^{10}$ per ml 2SPG (Wyrick et al. 1978), and frozen at $-70^{\circ} \mathrm{C}$. A sample of each frozen chlamydial stock was rapidly thawed at $37^{\circ} \mathrm{C}$ and prescreened for infectivity titres in coverslip cultures of McCoy cells before inoculation of genital cell cultures. After centrifuge-assisted inoculation, infected monolayers were incubated at $35{ }^{\circ} \mathrm{C}$ in an atmosphere of $5 \% \mathrm{CO}_{2}$ for 48 to $72 \mathrm{~h}$, stained with Giemsa Gurr (BDH) and percentages of inclusion-bearing cells were determined. Chlamydial stocks were subsequently diluted to produce infection in aproximately $50 \%-80 \%$ of the McCoy cells in a coverslip monolayer. 
The number of infectious EB per stock population is routinely $1 \%$ for purified preparations, even at a multiplicity of infection (m.o.i.) of less than one EB per McCoy cell. At high m.o.i. the possibility exists that titres may be artificially low if more than one infectious EB is ingested per host cell, and the developing EB-or reticulate body-containing phagosomes fuse (Ward, 1983; see legend for Fig. $1 d$ ). This would result in a host cell exhibiting a single chlamydial inclusion.

Isolation and culture of human genital cells. Tissue was obtained from women of childbearing age undergoing hysterectomy for non-malignant disease under a protocol approved by the institutional committee for the protection of human rights. The uterus was bisected from cervix to fundal dome and inspected for gross evidence of disease intrinsic to ectocervix and endometrium. Only tissues showing no macroscopic evidence of underlying pathology were used.

The method of Vesterinen et al. (1980a) was used for the establishment of squamous ectocervical cell cultures. Briefly, the underlying stroma was removed from ectocervical strips and the remaining epithelial layers were cut into $1 \mathrm{~mm}^{2}$ explants. Three to four explants were placed, stroma side down, on $13 \mathrm{~mm}$ diameter plastic tissue culture coverslips (Thermonox: Flow Laboratories) held in 24 well tissue culture plates or 7-10 explants were placed directly on the surface of $35 \times 10 \mathrm{~mm}$ tissue culture dishes (Falcon). MEM/D-valine was added to the culture vessels and explants were incubated at $35{ }^{\circ} \mathrm{C}$ in an atmosphere of $5 \% \mathrm{CO}_{2}$. This medium prevents contaminating fibroblast growth due to the inability of fibroblasts to convert D-amino acids into their essential $\mathrm{L}$ enantiomers (Gilbert \& Migeon, 1975). Squamous epithelial cells, capable of this conversion, grew out in a radial fashion from adherent explants to form confluent cell cultures within 10 to $15 \mathrm{~d}$. The epithelial nature of these cultures has been described (Vesterinen et al., 1980a,b). Ectocervical cultures were fed with fresh MEM/D-valine at $4 \mathrm{~d}$ intervals before $C$. trachomatis challenge.

A modification of the procedure of Satyaswaroop et al. (1979) and Varma et al. (1982) was used for the isolation and culture of human endometrial glands. Strips of endometrium were slivered using a scalpel and treated with $0.25 \%$ type IV collagenase (Sigma) in Hanks' balanced salts solution supplemented with 25 mM-HEPES buffer (Sigma), $200 \mu \mathrm{g}$ penicillin and $200 \mu \mathrm{g}$ streptomycin per ml, $\mathrm{pH} 7.4$ (HBSS/HEPES) for 60 to $90 \mathrm{~min}$ at $35^{\circ} \mathrm{C}$ in an atmosphere of $5 \% \mathrm{CO}_{2}$. Endometrial glands, containing columnar-cuboidal epithelial cells, were released by enzyme digestion while most of the remaining stroma was reduced to single cell constituents. The glands were separated from the stromal cells by differential centrifugation at $57 \mathrm{~g}$ for $15 \mathrm{~s}$. Sedimented glands were resuspended and washed three times in HBSS/HEPES and finally resuspended in DMEM. The suspension was distributed, at a density of 20 glands $\mathrm{ml}^{-1}$, to 24 well culture plates containing plastic coverslips or directly into $35 \times 10 \mathrm{~mm}$ culture dishes. All vessels used for the culture of endometrial tissue preparations were pretreated with $0-01 \mathrm{mg}$ bovine plasma fibronectin (BRL) per $\mathrm{ml} \mathrm{HBSS}$ for $60 \mathrm{~min}$ at $35^{\circ} \mathrm{C}$. Columnar epithelial cells grew out in a swirl pattern from adherent glands to form nearly confluent monolayers within 4 to $10 \mathrm{~d}$. Cultures were fed with fresh DMEM at 3 to $4 \mathrm{~d}$ intervals before chlamydial inoculation.

The epithelial purity of endometrial cell cultures was determined using alkaline phosphatase activity as a marker (Siegfried et al., 1984). The monolayers typically contained more than $90 \%$ alkaline phosphatase positive cells. HeLa 229 cultures were used as positive controls while L929 and McCoy fibroblast cultures served as negative controls.

Chlamydial infection of human genital cell cultures. Genital cells were used for chlamydial infection when the cultures were subconfluent ( 8 to $10 \mathrm{~d}$ for the ectocervical cells: 5 to $7 \mathrm{~d}$ for the endometrial cells). These cultures contained $>90 \%$ viable cells, as determined by trypan blue exclusion, at the time of chlamydial inoculation. EB inoculum $(0.2 \mathrm{ml})$ was added to each coverslip (column height $1 \mathrm{~mm}$ ) and the cultures were centrifuged at $375 \mathrm{~g}$ for $20 \mathrm{~min}$. Monolayers were washed twice with fresh medium and finally $1 \mathrm{ml}$ DMEM was added to each infected monolayer. The extent of infection was monitored by determining the percentages of inclusion-bearing cells with Giemsa stain, after incubation at $35^{\circ} \mathrm{C}$ in $5 \% \mathrm{CO}_{2}$ for $72 \mathrm{~h}$. Uninoculated genital cells, stained with Giemsa, served as negative controls in each experiment. No evidence of indigenous chlamydial infection was found in any of the human cell cultures used.

Association of radiolabelled $C$. trachomatis $E / U W-5$ with host cells. To measure the association of radiolabelled $C$. trachomatis EB with confluent cultures of genital and McCoy cells, ${ }^{3} \mathrm{H}$-labelled chlamydiae $\left({ }^{3} \mathrm{H}-\mathrm{E} / \mathrm{UW}-5\right)$, at a m.o.i. of 50 to 100 particles per host cell, were centrifuged at $375 \mathrm{~g}$ for 20 min onto $1-2 \times 10^{6}$ cells grown in $35 \mathrm{~mm}$ diameter tissue culture dishes. After inoculation, supernatants and cell monolayers were collected, placed on ice and precipitated in $5 \%(\mathrm{w} / \mathrm{v})$ trichloroacetic acid, and assayed according to the method of Wyrick et al. (1978). Duplicate monolayers were incubated in DMEM for 48 to $72 \mathrm{~h}$ to determine percentages of inclusion-bearing cells visible with Giemsa stain.

Statistics. Student's t-test was used to analyse and compare differences in (i) the extent of $C$. trachomatis infection of McCoy cells and genital cells, (ii) the effects of various host cell manipulations on percentages of inclusion-positive genital cells and association of ${ }^{3} \mathrm{H}-\mathrm{E} / \mathrm{UW}-5$ with host cells, and (iii) the effects of cell culture medium on inclusion development in genital and McCoy cell cultures. Results for which $P$ was $<0.05$ were defined as significant. 


\section{RESULTS}

Chlamydial infection of human genital cells. The results of initial studies conducted to determine if in vitro cultures of human genital cells would be susceptible to C. trachomatis infection are presented in Table 1. Two representative experiments are shown for each chlamydial biovar. Both genital cell types were susceptible to $C$. trachomatis challenge, but McCoy cells supported more inclusion development than either genital cell type. In all cases the difference in percentages of inclusion-positive McCoy cells versus genital cells was significant $(P \leqslant 0.005)$. The results from these experiments also indicated that columnar epithelial cells from endometrium supported chlamydial inclusion development to a greater extent than squamous epithelial cells derived from ectocervical explants $(P \leqslant 0.01)$. The time points indicated in Table 1 were optimal for counting the chlamydial inclusions in McCoy and genital cells.

Fig. $1(a, b)$ shows Giemsa-stained inclusions in ectocervical and endometrial cells infected with $C$. trachomatis. Inclusions in the human genital cells were confirmed as $C$. trachomatis inclusions with a fluorescein-labelled monoclonal antibody (Microtrak Culture Confirmation Test, Syva Co., Palo Alto, Calif., USA) (Fig. 1c).

Effects of various manipulations on the extent of chlamydial inclusion development in genital cell cultures. Further studies were done to examine the effects of various manipulations reported to influence the extent of chlamydial infection in tissue culture cells. Genital cell cultures were (i) treated with DEAE-dextran $\left(M_{\mathrm{r}} 500000\right.$; Pharmacia) at $30 \mu \mathrm{g} \mathrm{ml}^{-1}$ before chlamydial inoculation (Kuo et al., 1972), (ii) exposed to cycloheximide $(0.5 \mu \mathrm{g}$ per ml DMEM) after inoculation, or (iii) grown in the presence of female sex hormones (Kaufman et al., 1980): $10^{-7} \mathrm{M}-17-\beta$-oestradiol (Calbiochem) alone or $10^{-8} \mathrm{M}-17-\beta$-oestradiol in combination with $10^{-7} \mathrm{M}$-progesterone (Sigma).

The results of these treatments on the percentage of inclusion-bearing cells in the genital cell cultures are presented in Table 2. Each experiment represented tissue from a different patient. Pretreatment of either host cell with DEAE-dextran did not result in a significant increase in visibly infected cells. The addition of cycloheximide did result in a significant increase in the percentage of inclusion-positive ectocervical cells in experiments $1,2,3$ and 6 (Table $2 a$; $P \leqslant 0.04$ ) and inclusion-positive endometrial cells in experiments 4 and 6 (Table $2 b ; P=0.02$ ). Finally, growth of ectocervical cells in hormone-supplemented medium had no obvious effect on percentages of inclusion-positive cells (Table $2 a$ ), but there were some cases where decreases in percentages of inclusion-positive cells were noted for endometrial cultures maintained in DMEM supplemented with hormones (Table $2 b$ ). With medium containing $17-\beta$-oestradiol alone these decreases were significant for experiments 1 and $6(P \leqslant 0.03)$, while cell cultures maintained in medium supplemented with a combination of $17-\beta$-oestradiol and progesterone exhibited significant decreases, as observed in experiments 1,5 and $6(P \leqslant 0.01)$.

Association of radiolabelled C. trachomatis with genital cells. As a second approach to determine what effect(s) DEAE-dextran addition and hormone supplementation might have on chlamydial interactions with host cells, experiments were done to determine the extent of association of radiolabelled $C$. trachomatis with treated host cells immediately after inoculation. A representative experiment is shown in Table 3. Addition of DEAE-dextran resulted in a slight but non-significant enhanced association of radiolabelled organisms with all three cell types. Growth in medium supplemented with hormones resulted in a significant decrease in the percentage of host cell associated ${ }^{3} \mathrm{H}-\mathrm{E} / \mathrm{UW}-5$ with both genital cell types $(P \leqslant 0.02)$. In contrast, the association of ${ }^{3} \mathrm{H}-\mathrm{E} / \mathrm{UW}-5$ with McCoy cells was not reduced by culture in hormonesupplemented medium. Giemsa stain analysis of inclusion-positive cells in duplicate cultures highlighted the differences observed for ${ }^{3} \mathrm{H}-\mathrm{E} / \mathrm{UW}-5$ association with treated cells with the exception of the DEAE-dextran group. Finally, these results were confirmed in a second experiment utilizing genital cells from a different patient.

In the experiment described in Table 3, the ratio of $C$. trachomatis particles per host cell was $100: 1$ for endometrial and McCoy cells and 50:1 for ectocervical cells. We have no information concerning the concentration of $C$. trachomatis receptors on the different cell types or the level of C. trachomatis required for host cell receptor saturation. Therefore, it is difficult to compare the 


\section{Table 1. Extent of C. trachomatis infection of cultures of ectocervical, endometrial and McCoy cells}

$13 \mathrm{~mm}$ diameter plastic coverslip cultures of ectocervical, endometrial and McCoy cells, containing 1-2 $\times 10^{5}$ host cells, were inoculated with $C$. trachomatis by centrifugation at $375 \mathrm{~g}$ for $20 \mathrm{~min}$. Chlamydial inocula were adjusted to produce inclusions in approximately 50 to $70 \%$ of equivalent numbers of McCoy cells. The medium for endometrial and McCoy cell cultures was DMEM before and after chlamydial inoculation. The medium for ectocervical cell cultures was MEM/D-valine before and DMEM after chlamydial inoculation.

\begin{tabular}{|c|c|c|c|c|}
\hline \multirow[b]{2}{*}{ C. trachomatis } & \multirow[b]{2}{*}{ Expt } & \multirow{2}{*}{$\begin{array}{l}\text { Cell } \\
\text { type }\end{array}$} & \multicolumn{2}{|c|}{$\begin{array}{l}(\% \text { inclusion-positive genital cells }) / \\
(\% \text { inclusion-positive McCoy cells })^{*}\end{array}$} \\
\hline & & & . Ectocervical & Endometrial \\
\hline $\begin{array}{l}\text { Immunotype E } \\
(\mathrm{UW}-5) \dagger\end{array}$ & $\begin{array}{l}1 \\
2\end{array}$ & & $\begin{array}{r}5.8 \pm 0.94 / 53.8 \pm 1.0 \\
6.97 \pm 0.93 / 55.7 \pm 1.5\end{array}$ & $\begin{array}{l}22.0 \pm 2.4 / 60.7 \pm 1.2 \\
18.7 \pm 0.6 / 49.0 \pm 0.6\end{array}$ \\
\hline $\begin{array}{l}\text { LGV } \\
(\mathrm{L} 2 / 434)_{+}^{+}\end{array}$ & $\begin{array}{l}1 \\
2\end{array}$ & & $\begin{array}{l}9 \cdot 3 \pm 1 \cdot 5 / 57.5 \pm 2.5 \\
7.3 \pm 1 \cdot 5 / 57.5 \pm 2.5\end{array}$ & $\begin{array}{l}30.6 \pm 0.8 / 79.4 \pm 4.1 \\
36.7 \pm 3.1 / 73.3 \pm 1.5\end{array}$ \\
\hline
\end{tabular}

* Infection was determined by counting chlamydial inclusions, visible with Giemsa stain, in an average of 300 cells per coverslip culture. Results are means \pm SEM for triplicate cultures.

$\dagger$ Inclusions were counted $72 \mathrm{~h}$ post-inoculation.

$\ddagger$ Inclusions were counted $48 \mathrm{~h}$ post-inoculation.

extent of bacterial association with the different cell types. However, the association of ${ }^{3} \mathrm{H}-$ E/UW-5 appeared greater with McCoy cells than with either genital cell type. Similarly, the level of ${ }^{3} \mathrm{H}-\mathrm{E} / \mathrm{UW}-5$ association was approximately two-fold greater, on a per cell basis, with endometrial cells than with ectocervical cells (data not shown). These findings were in agreement with the three cell types with respect to the order of sensitivity to E/UW-5 infection determined by inclusion counting (Table 1).

Immunofluorescence analysis of early chlamydial interactions with genital and McCoy cell cultures. In a further attempt to investigate the nature of differences in the percentages of inclusion-bearing McCoy cells versus genital cells and endometrial cells versus ectocervical cells (Table 1), the pattern of E/UW-5 association with host cells was visualized by immunofluorescence with a fluorescein-labelled monoclonal antibody. Immediately after centrifugationassisted inoculation with E/UW-5, infected cultures were washed twice with HBSS/HEPES, fixed with methanol and reacted with antibody. Fluorescent chlamydial particles were associated with approximately $30 \%$ of the cells in endometrial cultures and $15 \%$ of the cells in ectocervical cultures. In contrast, approximately $70 \%$ of the McCoy cells possessed adherent and/or internalized E/UW-5 particles. In all cell types, the associated chlamydiae appeared evenly distributed over the infected cells. These results indicated that, unlike McCoy cell cultures, a high percentage of the cells in both endometrial and ectocervical cultures failed to adsorb $\mathrm{E} / \mathrm{UW}-\mathrm{5}$.

Centrifugation-assisted versus adsorption inoculation of genital cells. For adsorption inoculation, the same titre of infectious E/UW- 5 was resuspended in a much reduced fluid volume $(50 \mu \mathrm{l})$ and this inoculum was adsorbed to host cells for $60 \mathrm{~min}$ at $35^{\circ} \mathrm{C}$ with agitation at 5-10 min intervals. The results (Table 4) indicated that genital cells were as susceptible to chlamydial infection after adsorption inoculation as they were after centrifugation-assisted inoculation. Analogous experiments with McCoy cells gave similar results (data not shown). Increases in centrifugal force from $375 \mathrm{~g}$ to $1000 \mathrm{~g}$ and in the time of centrifugation from $20 \mathrm{~min}$ to $60 \mathrm{~min}$ did not result in increased percentages of inclusion-bearing McCoy cells. In both cases approximately $50 \%$ of the McCoy cells contained chlamydial inclusions visible with Giemsa stain $72 \mathrm{~h}$ postinoculation.

Effect of culture medium on E/UW-5 inclusion development. During our early studies on the interaction of $C$. trachomatis with human genital cell cultures, infections using MEM/D-valine resulted in a marked alteration, and, usually, reduction of inclusion development (Table 5). When inclusions did appear, they exhibited a distinct morphology, generally containing empty 

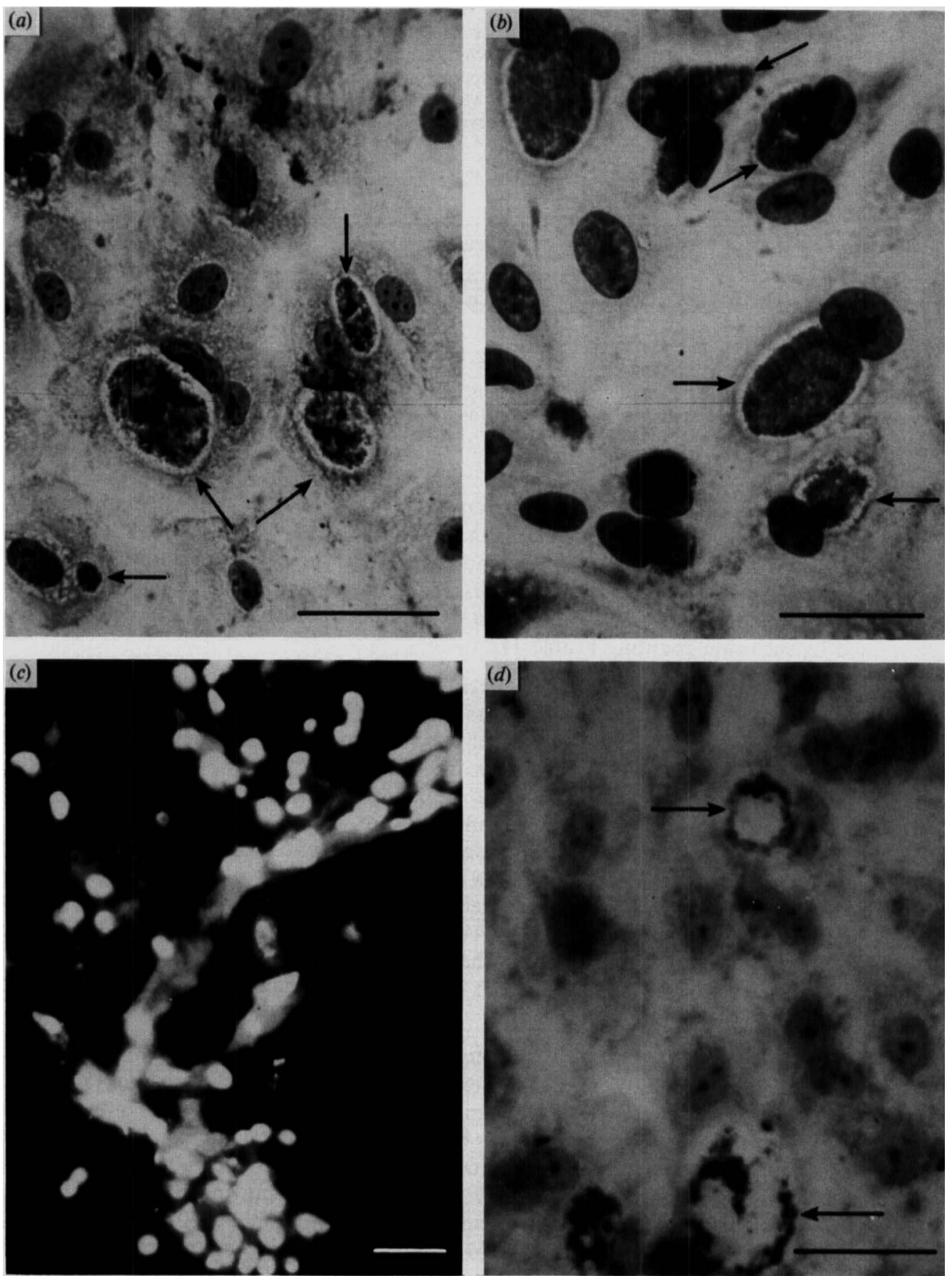

Fig. 1. C. trachomatis E/UW-5 inclusions (arrowed) in experimentally infected genital cell cultures $72 \mathrm{~h}$ post-inoculation. (a) Ectocervical cells and $(b)$ endometrial cells stained with Giemsa ; bars, $50 \mu \mathrm{m}$. $(c)$ Endometrial cells stained with fluorescent antibody; bar, $100 \mu \mathrm{m}$. (d) E/UW-5 inclusion morphology in MEM/D-valine: bar, $50 \mu \mathrm{m}$. 
Table 2. Effects of DEAE-dextran, cycloheximide and hormones on the extent of $C$. trachomatis $E / U W-5$ inclusion development in ectocervical and endometrial cell cultures

Host cell cultures on plastic coverslips, treated accordingly, were inoculated with $C$. trachomatis by centrifugation. Ectocervical cells were grown in MEM/D-valine before and DMEM after chlamydial inoculation. Endometrial cells were cultured in DMEM before and after chlamydial inoculation.

\begin{tabular}{|c|c|c|c|c|c|c|}
\hline \multirow[b]{2}{*}{ Expt } & \multirow[b]{2}{*}{$\begin{array}{l}\text { Cell } \\
\text { treatment* }\end{array}$} & \multicolumn{5}{|c|}{ Percentage of inclusion-positive cells $\dagger$} \\
\hline & & None & DEAE-dextran & Cycloheximide & Oestrogen & $\begin{array}{c}\text { Progesterone } \\
+ \text { oestrogen }\end{array}$ \\
\hline \multicolumn{7}{|c|}{ (a) Ectocervical cells } \\
\hline 1 & & $4.7 \pm 1.0$ & $5 \cdot 2 \pm 0 \cdot 4$ & $8.1 \pm 0.3 \ddagger$ & $4 \cdot 5 \pm 0 \cdot 1$ & $3 \cdot 9 \pm 0 \cdot 1$ \\
\hline 2 & & $3.6 \pm 0.2$ & $7.9 \pm 0.3 \ddagger$ & $10.9 \pm 0.8 \ddagger$ & $6 \cdot 3 \pm 0.3$ & $3 \cdot 4 \pm 0 \cdot 3$ \\
\hline 3 & & $8.0 \pm 0.4$ & $8.1 \pm 0.8$ & $10.4 \pm 0.3 \ddagger$ & - & - \\
\hline 4 & & $5.8 \pm 0.9$ & $7 \cdot 0 \pm 0 \cdot 1$ & $5.4 \pm 0.7$ & - & 一 \\
\hline 5 & & $13.9 \pm 0.6$ & - & $17 \cdot 0 \pm 1.2$ & $14 \cdot 2 \pm 2 \cdot 2$ & $13.5 \pm 0.5$ \\
\hline 6 & & $11.6 \pm 0.9$ & - & $15.5 \pm 0.8 \ddagger$ & $9.8 \pm 0.3$ & $9.7 \pm 0.5$ \\
\hline \multicolumn{7}{|c|}{ (b) Endometrial cells } \\
\hline 1 & & $11 \cdot 5 \pm 0.3$ & $15 \cdot 0 \pm 0 \cdot 2$ & - & $6.8 \pm 1.2_{+}^{+}$ & $7.6 \pm 0.7 \pm$ \\
\hline 2 & & $13.5 \pm 1.4$ & $13.8 \pm 0.8$ & - & $13.9 \pm 1.0$ & $13.1 \pm 0.7$ \\
\hline 3 & & $20.0 \pm 1.7$ & $20.9 \pm 3.1$ & $24 \cdot 6 \pm 0.5$ & - & - \\
\hline 4 & & $18.7 \pm 0.6$ & $18.5 \pm 1.0$ & $23 \cdot 3 \pm 1.7 \ddagger$ & - & - \\
\hline 5 & & $21.6 \pm 0.2$ & $22 \cdot 2 \pm 4 \cdot 2$ & $28.0 \pm 4.0$ & $22.4 \pm 0.2$ & $19.0 \pm 0.2_{t}^{+}$ \\
\hline 6 & & $17.4 \pm 1.5$ & $16.8 \pm 1.3$ & $22.4 \pm 0.8 \ddagger$ & $11.4 \pm 1.4_{+}^{+}$ & $9 \cdot 5 \pm 1 \cdot 1+$ \\
\hline
\end{tabular}

* DEAE-dextran at $30 \mu \mathrm{g}$ per ml HBSS ; cycloheximide at $0.5 \mu \mathrm{g}$ per $\mathrm{ml}$ DMEM after inoculation; cells grown in medium with $17-\beta$-oestradiol $\left(10^{-7} \mathrm{M}\right)$ or medium with a combination of progesterone $\left(10^{-7} \mathrm{M}\right)$ and $17-\beta$-oestradiol $\left(10^{-8} \mathrm{M}\right)$.

$\dagger$ Determined by Giemsa staining $72 \mathrm{~h}$ post-inoculation. In $(a)$ the corresponding levels of inclusion-positive McCoy cells, grown in DMEM, were $49 \%, 54 \%$ and $71 \%$ for experiments 1 and 2,3 and 4 and 5 and 6 , respectively. In $(b)$ the corresponding levels of inclusion-positive McCoy cells were $36 \%, 49 \%, 54 \%, 59 \%, 52 \%$ and $47 \%$ for experiments 1 to 6 , respectively. Results are means \pm SEM for duplicate to triplicate coverslip cultures.

$\ddagger$ Indicates where $P$ values obtained from comparisons of the various cell treatments versus no treatment were $<0.05$.

Table 3. Effects of DEAE-dextran and hormones on the association of ${ }^{3} \mathrm{H}$-labelled C. trachomatis E/UW-5 with genital and McCoy cell cultures

Endometrial and McCoy cell cultures, containing $1 \times 10^{6}$ cells per $35 \mathrm{~mm}$ diameter culture dish, were maintained in DMEM before chlamydial inoculation. Ectocervical cell cultures, containing $2 \times 10^{6}$ cells per $35 \mathrm{~mm}$ diameter culture dish, were maintained in MEM/D-valine before chlamydial inoculation. Host cells were inoculated with ${ }^{3} \mathrm{H}$-labelled $C$. trachomatis by centrifugation. The chlamydial particle to host cell ratio was $100: 1$ for endometrial and McCoy cells and 50:1 for ectocervical cells.

\begin{tabular}{|c|c|c|c|c|c|}
\hline \multirow[b]{2}{*}{ Cell type } & \multirow[b]{2}{*}{$\begin{array}{l}\text { Cell } \\
\text { treatment* }\end{array}$} & \multicolumn{4}{|c|}{ Percentage cell-associated TCA-precipitable counts $\dagger$} \\
\hline & & None & $\begin{array}{l}\text { DEAE- } \\
\text { dextran }\end{array}$ & Oestrogen & $\begin{array}{c}\text { Progesterone } \\
+ \text { oestrogen }\end{array}$ \\
\hline Endometrial & & $\begin{array}{c}26 \cdot 0 \pm 0.5 \\
(15 \cdot 8) \ddagger\end{array}$ & $\begin{array}{c}31 \cdot 7 \pm 0.3 \\
(15 \cdot 7)\end{array}$ & $\begin{array}{c}16.4 \pm 0.8 \S \\
(8 \cdot 3)\end{array}$ & $13 \cdot 3 \underset{(6 \cdot 1)}{ \pm} 0 \cdot 3 \S$ \\
\hline Ectocervical & & $\begin{array}{c}21 \cdot 1 \pm 1 \cdot 8 \\
(11 \cdot 2)\end{array}$ & $\begin{array}{c}27 \cdot 0 \pm 1 \cdot 6 \\
(10 \cdot 2)\end{array}$ & $13 \cdot 4 \pm 1.6 \S$ & $12 \cdot 2 \pm 2.0 \S$ \\
\hline McCoy & & $\begin{array}{c}45 \cdot 6 \pm 1 \cdot 3 \\
(59 \cdot 5)\end{array}$ & $\begin{array}{c}52 \cdot 4 \pm 3 \cdot 0 \\
(60 \cdot 3)\end{array}$ & $\underset{(56 \cdot 3)}{53 \cdot 3 \pm 6 \cdot 3}$ & $\begin{array}{c}55 \cdot 0 \pm 8 \cdot 2 \\
(51 \cdot 1)\end{array}$ \\
\hline
\end{tabular}

* As described in Table 2.

$\dagger$ Percentages of cell-associated TCA-precipitable (ppt) counts were calculated as follows: $\%=[($ cell-associated ppt counts)/(cell-free ppt counts + cell-associated ppt counts)] $\times 100$.

$\ddagger$ Numbers in parentheses are the percentage of inclusion-positive cells visible with Giemsa stain $72 \mathrm{~h}$ postinoculation.

$\S P$ values for ${ }^{3} \mathrm{H}-\mathrm{E} / \mathrm{UW}-5$ association with genital cells in hormone-supplemented medium versus nonsupplemented medium were $\leqslant 0 \cdot 02$. 
Table 4. Infection of genital cell cultures after centrifugation-assisted or adsorption inoculation with C. trachomatis $E / U W-5$

Before chlamydial inoculation endometrial cells were grown in DMEM and ectocervical cells were grown in MEM/D-valine. The post-inoculation culture medium for both cell types was DMEM. Chlamydial particles suspended in $0.2 \mathrm{ml}$ DMEM were centrifuged onto host cells at $375 \mathrm{~g}$ for $20 \mathrm{~min}$. Equivalent numbers of chlamydial particles, suspended in $50 \mu \mathrm{l}$ DMEM, were adsorbed to host cells at $35^{\circ} \mathrm{C}$ for $60 \mathrm{~min}$.

$\begin{array}{llcr}\text { Expt } & \text { Cell type } & \overbrace{\text { Centrifugation }}^{\begin{array}{c}\text { Percentage of inclusion-positive } \\ \text { cells after:* }\end{array}} & \text { Adsorption } \\ 1 & \text { Endometrial } & 25.0 \pm 1.8 & 23.3 \pm 0.6 \\ 2 & \text { Endometrial } & 20.0 \pm 1.7 & 20.7 \pm 0.5 \\ 1 & \text { Ectocervical } & 8.0 \pm 0.4 & 6.8 \pm 0.5 \\ 2 & \text { Ectocervical } & 5.8 \pm 0.9 & 5.1 \pm 0.4\end{array}$

* Determined by Giemsa staining $72 \mathrm{~h}$ post-inoculation. Results are means \pm SEM for triplicate coverslip cultures.

Table 5. Effect of cell culture medium on $C$. trachomatis $E / U W-5$ inclusion development in genital and McCoy cell cultures

Host cells were inoculated with C. trachomatis by centrifugation. Endometrial and McCoy cell cultures were maintained in DMEM before inoculation. Ectocervical cell cultures were maintained in MEM/Dvaline before inoculation.

\begin{tabular}{|c|c|c|c|c|}
\hline \multirow[b]{2}{*}{ Expt } & \multirow[b]{2}{*}{ Cell type } & \multirow{2}{*}{$\begin{array}{l}\text { Post-inoculation } \\
\text { medium ... }\end{array}$} & \multicolumn{2}{|c|}{ Percentage of inclusion-positive cells* } \\
\hline & & & DMEM† & MEM/D-valine \\
\hline 1 & Endometrial & & $25 \cdot 0 \pm 1.8$ & $4.6 \pm 0.6$ \\
\hline 2 & Endometrial & & $18.7 \pm 0.6$ & $2.2 \pm 0.4$ \\
\hline 1 & Ectocervical & & $7.9 \pm 0.3$ & $0.41 \pm 0.1$ \\
\hline 2 & Ectocervical & & $9.3 \pm 0.8$ & $0.25 \pm 0.1$ \\
\hline 1 & McCoy & & $52 \cdot 3 \pm 1 \cdot 3$ & $1.0 \pm 0.3$ \\
\hline 2 & McCoy & & $53.2 \pm 0.5$ & $6.0 \pm 2.4$ \\
\hline
\end{tabular}

* Determined by Giemsa staining $72 \mathrm{~h}$ post-inoculation. Results are means \pm SEM.

$\dagger$ With all cell types the level of infection was significantly greater in DMEM than in MEM/D-valine $(P \leqslant 0 \cdot 001)$.

centres with a few chlamydiae lining the periphery of the inclusion membrane (Fig. $1 d$ ). This reduction of E/UW-5 inclusion development was significant for both genital and McCoy cell cultures $(P \leqslant 0.001)$. Since there were no differences in the initial attachment and internalization of E/UW-5 particles by host cells in MEM/D-valine or DMEM, we decided to investigate the possibility that inhibition of inclusion development in $M E M / D$-valine was the result of nutrient deprivation (Allan \& Pearce, 1983).

Various methods were used in an effort to reverse the inhibition of inclusion development observed in $\mathrm{MEM} / \mathrm{D}$-valine, including addition of $4 \mathrm{mM}-\mathrm{L}$-valine to basal MEM/D-valine, addition of cycloheximide at $0.5 \mu \mathrm{g}$ per $\mathrm{ml} \mathrm{MEM} / \mathrm{D}$-valine after chlamydial inoculation and culture of host cells in DMEM after chlamydial inoculation. With endometrial cells (Table $6 a$ ), no post-inoculation culture condition was capable of returning the level of inclusion development to that observed in DMEM or DMEM plus cycloheximide. The addition of cycloheximide and L-valine to basal MEM/D-valine did result in a slight increase in percentages of inclusion-bearing cells when compared to MEM/D-valine alone. However, these percentages were significantly lower than the percentage of inclusion-positive endometrial cells cultured in $\operatorname{DMEM}(P \leqslant 0.003)$. In contrast, addition of either cycloheximide or L-valine to basal MEM/D- 
Table 6. Effects of various culture conditions on $C$. trachomatis $E / U W-5$ inclusion development

Coverslip cultures of endometrial and McCoy cells were maintained in DMEM before centrifugationassisted inoculation with $C$. trachomatis. Ectocervical cells were maintained in MEM/D-valine before inoculation with $C$. trachomatis. At $0,24,48$ and $72 \mathrm{~h}$ post-inoculation the culture medium was changed from MEM/D-valine to one of the indicated conditions.

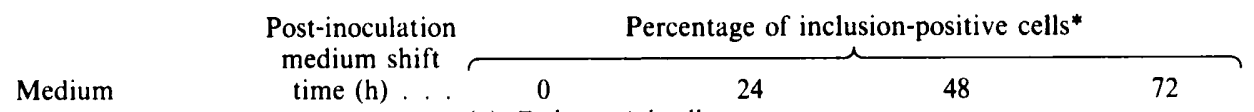

(a) Endometrial cells

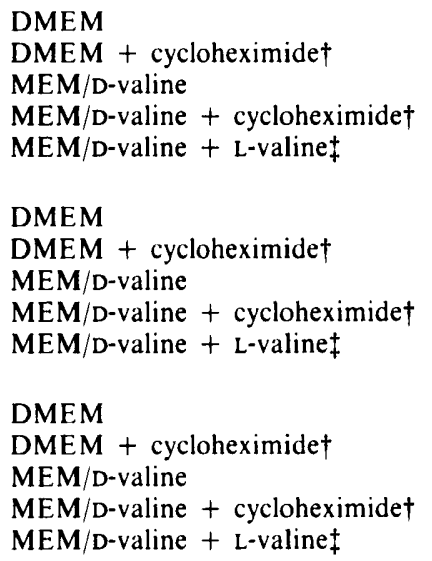

$\begin{array}{rr}21.0 \pm 0.3 & 10.3 \pm 1.5 \\ 27.4 \pm 0.6 & 14.7 \pm 0.4 \\ 1.3 \pm 0.2 & 0.8 \pm 0.3 \\ 4.8 \pm 1.2 & 5.7 \pm 0.9 \\ 7.1 \pm 0.5 & 2.3 \pm 0.2\end{array}$

$4.9 \pm 0.4$
$8.8 \pm 0.2$
$1 \cdot 1 \pm 0.4$
$2 \cdot 6 \pm 0.4$
$2 \cdot 0 \pm 0.3$

$0 \cdot 6 \pm 0 \cdot 2$

$1 \cdot 1 \pm 0 \cdot 4$

$0 \cdot 1 \pm 0 \cdot 1$

$0.9 \pm 0 \cdot 2$

(b) Ectocervical cells

$\begin{array}{rllc}7.0 \pm 0.9 & 5.4 \pm 0.3 & 2.3 \pm 0.2 & 0.8 \pm 0.2 \\ 12.4 \pm 0.2 & 8.8 \pm 1.9 & 3.2 \pm 0.1 & 2.0 \pm 0.3 \\ 0.2 \pm 0.1 & 0.3 \pm 0.3 & 0.1 \pm 0.1 & 0.0 \\ 12.9 \pm 0.5 & 7.7 \pm 1.6 & 3.2 \pm 1.3 & 1.3 \pm 0.5 \\ 4.7 \pm 0.2 & 2.1 \pm 0.1 & 0.9 \pm 0.2 & 1.3 \pm 0.1\end{array}$

(c) $\mathrm{McCoy}$ cells

$\begin{array}{rrrl}\text { (c) McCoy cells } & & \\ 52.3 \pm 1.3 & 35.8 \pm 2.9 & 10.9 \pm 0.8 & 2.1 \pm 0.4 \\ 77.8 \pm 2.7 & 47.9 \pm 2.3 & 14.9 \pm 0.5 & 1.6 \pm 0.6 \\ 1.0 \pm 0.3 & 0.8 \pm 0.1 & 1.9 \pm 0.4 & 0.4 \pm 0.02 \\ 78.2 \pm 1.4 & 46.8 \pm 0.3 & 11.6 \pm 0.5 & 1.6 \pm 0.7 \\ 51.1 \pm 1.0 & 26.9 \pm 0.8 & 11.8 \pm 0.6 & 0.8 \pm 0.1\end{array}$

* Inclusions were counted in an average of 300 cells per Giemsa-stained coverslip culture $72 \mathrm{~h}$ after shifts in media. Triplicate samples were run for each time and each medium condition. Results are means \pm SEM.

+ Cycloheximide at $0.5 \mu \mathrm{g}$ (ml culture medium $)^{-1}$.

$\ddagger \mathrm{L}-\mathrm{V}$ aline at $4 \mathrm{~mm}$.

valine returned the percentage of inclusion-positive ectocervical cells and McCoy cells to those levels observed when DMEM plus cycloheximide or DMEM alone were used as the postinoculation media, respectively (Table $6 b$ and $c$ ). In concurrent experiments, where MEM/Dvaline was maintained in the cultures for 24,48 and $72 \mathrm{~h}$ post-inoculation and then shifted to a growth-permissive condition, a nearly constant decrease in the percentage of inclusion-positive cells was observed, indicating that the growth potential of internalized E/UW-5 was gradually lost in MEM/D-valine. These results were confirmed on two separate occasions with each cell type.

\section{DISCUSSION}

Chlamydial genital infection in the adult female human involves the columnar epithelium lining mucosal surfaces of the uterus (Swanson et al., 1975; Mårdh et al., 1981) and fallopian tubes (Moller et al., 1979) but not the squamous epithelium of the ectocervix (Evans, 1982; Mitao et al., 1984). C. trachomatis is capable of infecting the atrophic squamous epithelium of the anoestiogenic prepubertal vagina to cause vaginitis (Bump, 1985). In the current study interaction with two different genital cell types was investigated. The columnar epithelial cell cultures were susceptible to chlamydial infection, yielding a reproducible infection rate of approximately $20 \%$ despite heterogeneity in the genetic background of tissue donors. However, this infection rate was far less than might be expected for a major target cell, perhaps suggesting some intrinsic resistance of endometrial epithelium to chlamydial infection; a factor which could contribute to the nature of $C$. trachomatis infection in vivo. In humans, $C$. trachomatis is noted for giving rise to chronic infections which are often inapparent or asymptomatic. A limitation in the number of susceptible cells on a given mucosal surface suggests a possible mechanism, other than host immune response, which may play a role in controlling the severity of infections in vivo. 
Limited growth of chlamydiae in the squamous cell cultures derived from ectocervical explants also occurred. It is not clear whether infection in these cells represents a previously unrecognized reservoir for chlamydial infection, an in vitro alteration in susceptibility to $C$. trachomatis challenge, or a possible contamination with susceptible squamocolumnar epithelial cells. The squamous cells that emerge from ectocervical explants are viable, dividing, nucleated cells most probably originating from the basal layers of the explants. Our culture methods may therefore have by-passed the normal organization of host-protective cell layers to expose susceptible cells which may not normally encounter infectious chlamydiae during the course of a natural infection.

Several explanations are possible for the low infection rates of genital cells compared with McCoy cells. One possibility, a partial adaptation of $C$. trachomatis to McCoy cells resulting from propagation in this cell line, was not directly examined in this study. Another is that internalized chlamydiae failed to develop into visible inclusions. This certainly occurred in cultures of both genital and McCoy cells but only in a small percentage of those cells. The major determinant in the degree of host cell susceptibility appeared to be a difference in the initial association of E/UW-5 with the three cell types. Immunofluorescence staining of cell-associated chlamydiae, immediately after inoculation, demonstrated that many cells in endometrial and ectocervical cultures were resistant to challenge at this early stage of infection. Supporting evidence was obtained from comparisons of the level of ${ }^{3} \mathrm{H}-\mathrm{E} / \mathrm{UW}-5$ association, adjusted for equivalent numbers of the different host cells; an order of association identical to the order of sensitivity determined with Giemsa and immunofluorescence staining techniques was observed. Other investigators have also observed an irregular distribution of adherent microorganisms with primary cultures of human epithelium. Stephens et al. (1983) reported that piliated Neisseria meningitidis bound preferentially to non-ciliated cells in nasopharyngeal organ cultures. Studies on the attachment of Neisseria gonorrhoeae to explants of human genital tract epithelium revealed that gonococci adhered in higher numbers to the transitional cells of cervical tissue than to squamous or fallopian tube epithelium (Draper et al., 1980). Sobel et al. (1982), using a vaginal explant culture system, observed bacterial and fungal adherence at higher levels to epithelial cells in the process of desquamation. It is tempting to speculate that resistance to chlamydial attachment results from the absence of specific receptors on many of the genital cells, perhaps as a function of cell cycle stages and/or different states of cellular differentiation.

In an effort to examine further the resistance/sensitivity of the genital cells to $C$. trachomatis infection we used various manipulations known to alter the susceptibility of HeLa and McCoy cells to the trachoma biovar strains. Treatment with the polycation DEAE-dextran has been reported to increase infections in host cells (Kuo et al., 1972; Rota \& Nichols, 1973; Soderlund \& Kihlstrom, 1982). In HeLa cells this may involve neutralization of the negatively charged host cell surface, allowing the negatively charged chlamydiae a sufficiently close approach for adsorption to target receptors (Kuo et al., 1973). Chlamydiae apparently lack a smooth lipopolysaccharide and pilus surface appendages used by other mucosal pathogens to bridge electronegative barriers between bacterium and host. Inoculation of cell cultures by centrifugation also enhances infection (Weiss \& Dressler, 1960; Darougar et al., 1974). In our hands neither of these two enhancement techniques altered the extent of chlamydial infection in the genital or McCoy cell cultures. The reason(s) for this lack of enhancement is unknown, but these experiments suggest a basic difference, perhaps at the level of the host cell surface, between the cultures we have used and the HeLa and McCoy cultures used in other studies. However, our experience for several years has shown that centrifugation up to $1000 \mathrm{~g}$ does not increase the number of cells infected by our $C$. trachomatis or $C$. psittaci strains if the EB are suspended in a very small volume of inoculum. The diffusion rate of this non-motile parasite, governed by Brownian motion, in the presence of $0.1 \mathrm{M}$-salts is evidently adequate to permit infection by adsorption.

During the menstrual cycle, the epithelial and stromal components of human endometrium undergo both structural and biochemical changes in response to variations in steroid hormone concentration. The influence of hormones on genital chlamydial infection in the adult female is 
not clear. It has been observed that women taking oral contraceptives appear to be at reduced risk from ascending spread of cervical infection (Senanayake \& Kramer, 1980), although it is not known whether this situation is due to a decrease in target cell susceptibility or to increased mucus production in the cervix which in turn blocks the ascent of infectious chlamydial particles. The effect of hormone supplementation of the medium on the sensitivity of cells to chlamydial infection has recently been investigated using some other cell culture systems. HeLa cells, incubated in medium supplemented with 17- $\beta$-oestradiol exhibited increased sensitivity to the agent of guinea pig inclusion conjunctivitis (Moses et al., 1984). In contrast, female sex hormones in high concentrations have been reported to 'negatively influence' chlamydial infection in McCoy cells (Mårdh, 1981). Our results on the effect of hormones on infection in genital cells must be interpreted with caution since the physical separation of epithelial cells from the stromal cell component of endometrium may result in a lack of hormone responsiveness in the cultured epithelial cells (Kirk \& Irwin, 1980; Satyaswaroop \& Mortel, 1981). Measurements of ${ }^{3} \mathrm{H}-\mathrm{E} / \mathrm{UW}-5$ association with the genital cells revealed a decrease in association for cells cultured in hormone-supplemented medium, indicating that the effect on host susceptibility may result through alterations in attachment and/or internalization of chlamydiae by these cells. In contrast, association of ${ }^{3} \mathrm{H}-\mathrm{E} / \mathrm{UW}-5$ with McCoy cells was unaffected by growth in hormone-containing medium.

There was a marked inhibition of inclusion development when MEM/D-valine was used for the culture of infected ectocervical cells. This effect was reproduced with endometrial and McCoy cell cultures, indicating that cell type was not a determining factor. Since L-valine is a required amino acid for chlamydial growth in McCoy cells (Allan \& Pearce, 1983), it is possible that its absence from MEM/D-valine accounted for both the reduction in inclusion number and the abnormal inclusion morphology observed with this medium. Addition of cycloheximide or Lvaline to MEM/D-valine after E/UW-5 inoculation returned the level of inclusion-bearing ectocervical and McCoy cells to approximately the same level observed when DMEM was used as the post-inoculation culture medium. This observation was analogous to that described by Hatch (1975) in which $C$. psittaci growth in L cells had been inhibited by isoleucine starvation. Apparently, if a required amino acid is absent or below a threshold level, then chlamydial growth does not ensue. The inhibition may be reversed if the appropriate amino acid is exogenously added or indigenously supplied as a result of host protein turnover in the presence of the eukaryotic protein synthesis inhibitor cycloheximide. Freedom from the inhibitory effect of MEM/D-valine could not be completely achieved with endometrial cells, although a slight increase in the percentage of inclusion-positive cells did occur in the presence of cycloheximide and L-valine. This failure may underlie a difference in the transport of L-valine by endometrial cells or the rate at which this amino acid is consumed and made available for chlamydial metabolism.

It has been suggested by others that the limited availability of required nutrients may in part contribute to the persistent, subclinical nature of chlamydial infections in humans and other animals (Morgan, 1956; Hatch, 1975). It is not difficult to envisage a latent infection in which respiring but non-multiplying chlamydiae survive within phagosomes of host cells, protected from specific immune defences until nutrient conditions arise which favour growth and replication. If such situations occur in vivo, then it should be possible to mimic this situation in tissue culture cells. Therefore, the time span over which inhibited inclusion development could be reversed in genital and McCoy cell cultures was examined. In all cell types there was a nearly constant decrease in the number of inclusion-positive cells for each increase in the time at which medium was shifted to a growth-permissive condition. These findings suggest that the growth potential of internalized E/UW-5 is gradually lost in the absence of required L-valine. However, it is possible that we have not used the proper condition(s) required to stimulate resumption of chlamydial multiplication in cells containing viable E/UW-5.

It is evident from our studies that several differences exist between the cultures we have used and the HeLa and McCoy cell cultures used by others. It is likely that future studies will reveal still more differences. There are potential pitfalls in using the primary genital cell cultures, including (i) the quantity of tissue that can be obtained from a given patient, (ii) the limited life 
span of primary epithelial cells in culture, (iii) the necessity of making comparisons with tissue from genetically heterogeneous donors and (iv) the continued availability of endometrial and ectocervical tissue. However, we believe that the merits of this system outweigh the disadvantages. Most importantly, the use of these cultures provides us with a unique opportunity to study the interaction of $C$. trachomatis with its natural human target tissue. Experimentation with natural target cells should enhance our chances of identifying features of both host and parasite which contribute to the nature of chlamydial infections in vivo.

The authors gratefully acknowledge Dr William Forrest, Charles Lee and James Shaver for their assistance in obtaining endometrial and cervical tissues. We also thank Drs Richard Hodinka and Eric Kihlstrom for reviewing the manuscript, and Lori Anderson for skillful secretarial assistance.

This investigation was supported by a Public Health Service Grant AI13446 from the National Institute for Allergy and Infectious Diseases.

\section{REFERENCES}

Allan, I. \& Pearce, J. H. (1983). Amino acid requirements of strains of Chlamydia trachomatis and C. psittaci growing in McCoy cells: relationship with clinical syndrome and host origin. Journal of General Microbiology 129, 2001-2007.

BUMP, R. C. (1985). Chlamydia trachomatis as a cause of perpubertal vaginitis. Obstetrics and Gynecology 65 , 384-388.

Croy, T. R., Kuo, C. C. \& Wang, S. P. (1975). Comparative susceptibility of eleven mammalian cell lines to infection with trachoma organisms. Journal of Clinical Microbiology 1, 434-439.

Darougar, S., CubitT, S. \& JoNES, B. R. (1974). Effect of high-speed centrifugation on the sensitivity of irradiated McCoy cell culture for the isolation of Chlamydia. British Journal of Venereal Diseases 50, 308-312.

Draper, D. L., Donegan, E. A., James, J. F., Sweet, R. L. \& BRooKs, G. F. (1980). Scanning electron microscopy of attachment of Neisseria gonorrhoeae colony phenotypes to surfaces of human genital epithelia. American Journal of Obstetrics and Gyneco$\log y 138,818-826$.

Evans, B. A. (1982). Chlamydial infection of the human cervix - an ultrastructural study. Journal of Infection 4, 225-228.

Gilbert, S. F. \& Migeon, B. R. (1975). D-Valine as a selective agent for normal human and rodent epithelial cells in culture. Cell 5, 11-17.

GoRDON, F. B. \& QuAN, A. L. (1965). Isolation of the trachoma agent in cell culture. Proceedings of the Society for Experimental Biology and Medicine 118, 354-359.

HARrison, H. R. \& Riggin, R. T. (1979). Infection of untreated primary human amnion monolayers with Chlamydia trachomatis. Journal of Infectious Diseases 140, 968-971.

Hatch, T. P. (1975). Competition between Chlamydia psittaci and $\mathrm{L}$ cells for host isoleucine pools: a limiting factor in chlamydial multiplication. Infection and Immunity 12, 211-220.

Hutchinson, G. R., Taylor-Robinson, D. \& DourMASHKIN, R. R. (1979). Growth and effect of chlamydiae in human and bovine oviduct organ cultures. British Journal of Venereal Diseases 55, 194202.
Kaufman, D. G., Adamec, T. A., Walton, L. A., Carney, C. N., Melin, S. A., Genta, V. M., Mass, M. J., Dorman, B. H., Rogers, W. T., Photopulos, G. J., Powell, J. \& Grisham, J. W. (1980). Studies of human endometrium in organ culture. Methods in Cell Biology, 21B, 1-27.

KIRK, D. \& IRWIN, J. C. (1980). Normal human endometrium in cell culture. Methods in Cell Biology 21B, $51-77$

Kuo, C. C., Wang, S. P., Wentworth, B. B. \& Grayston, J. T. (1972). Primary isolation of TRIC organisms in HeLa 229 cells treated with DEAEdextran. Journal of Infectious Diseases 125, 665-668.

Kuo, C. C., Wang, S. P., \& Grayston, J. T. (1973). Effect of polycations, polyanions, and neuraminidase on the infectivity of trachoma-inclusion conjunctivitis and lymphogranuloma venereum organisms in HeLa cells: sialic acid residues as possible receptors for trachoma-inclusion conjunctivitis. Infection and Immunity 8, 74-79.

Kuo, C. C., Wang, S. P. \& Grayston, T. J. (1977). Growth of trachoma organisms in HeLa 229 cell culture. In Nongonococcal Urethritis and Related Infections, pp. 328-336. Edited by D. Hobson \& K. K. Holmes. Washington, DC : American Society for Microbiology.

MARDH, P. A. (1981). Body fluids and constituents of body fluids influencing the formation of chlamydial inclusions in McCoy cell cultures. In Abstracts of the IVth International Meeting on Sexually Transmitted Diseases, p. 82. Heidelberg: International Society for STD Research.

MÅrdh, P. A., Moller, B. R., Ingerselu, H. J., Nussler, E., Westrom, L. \& WoIner-Hanssen, P. (1981). Endometritis caused by Chlamydia trachomatis. British Journal of Venereal Diseases 57, 191-195.

Mitao, M., ReumanN, W., Winkler, B., Richart, R., Fujiwara, A. \& CRUM, C. (1984). Chlamydial cervicitis and cervical intraepithelial neoplasia: an immunohistochemical analysis. Gynecology and $\mathrm{On}$ cology 19, 90-97.

Moller, B. R., Westrom, L., Ahrons, S., Ripa, K. T., Svensson, L., von MECKLEnburG, C., Henrikson, H. \& MÅDH, P. A. (1979). Chlamydia trachomatis infection of the fallopian tubes. British Journal of Veneral Diseases 55, 422-428. 
MORGAN, H. R. (1956). Latent viral infection of cells in tissue culture. I. Studies on latent infection of chick embryo tissues with psittacosis virus. Journal of Experimental Medicine 103, 37-47.

Moses, E. B., Peck, E. J., Jr \& Barron, A. L. (1984). Effect of estradiol on the growth of the Chlamydia agent of guinea pig inclusion conjunctivitis in cell culture. In Abstracts of the Annual Meeting of the American Society for Microbiology, abstract no. D12. St Louis: American Society for Microbiology.

NeWhall, W. J., BatTeIger, B. \& Jones, R. B. (1982). Analysis of human serological response to proteins of Chlamydia trachomatis. Infection and Immunity 38, 1181-1189.

RIPA, K. T. \& MÅRDH, P. A. (1977). Cultivation of Chlamydia trachomatis in cycloheximide-treated McCoy cells. Journal of Clinical Microbiology 6, 328331.

Rota, T. R. \& Nichols, R. L. (1973). Chlamydia trachomatis in cell culture. I. Comparison of efficiencies of infection in several chemically defined media, at various $\mathrm{pH}$ and temperature values, and after exposure to diethylaminoethyl-dextran. Applied Microbiology 26, 560-565.

SATYASWAROOP, P. G. \& MORTEL, R. (1981). Endometrial carcinoma: an aberration of endometrial cell differentiation. American Journal of Obstetrics and Gynecology 140, 620-623.

Satyaswaroop, P. G., Bressler, R. S., De laPena, M. M. \& GURPIDE, E. (1979). Isolation and culture of human endometrial glands. Journal of Clinical Endocrinology and Metabolism 48, 639-641.

SCHACHTER, J. \& DAwson, C. R. (1978). Human Chlamydial Infections. Littleton, Mass.: PSG Publishing Co.

Senanayake, P. \& Kramer, D. G. (1980). Contraception and the etiology of pelvic inflammatory disease: new perspectives. American Journal of Obstetrics and Gynecology 138, 852-860.

Siegfried, J. M., Nelson, K. G., Martin, J. L. \& KaUfman, D. G. (1984). Histochemical identification of cultured cells from human endometrium. In Vitro 20, 25-32.

Sobel, J. D., Myers, P., Levison, M. E. \& Kaye, D. (1982). Comparison of bacterial and fungal adher- ence to vaginal exfoliated epithelial cells and human vaginal epithelial tissue culture cells. Infection and Immunity 35, 697-701.

Soderlund, G. \& Kihlstrom, E. (1982). Physiochemical surface properties of elementary bodies from different serotypes of Chlamydia trachomatis and their interaction with mouse fibroblasts. Infection and Immunity 36, 893-899.

Stephens, D. S., Hoffman, L. H. \& MCGeE, Z. A. (1983). Interaction of Neisseria meningitidis with human nasopharyngeal mucosa: attachment and entry into columnar epithelial cells. Journal of Infectious Diseases 148, 369-376.

Swanson, J., Eschenbach, D. A., Alexander, E. R. \& Holmes, K. K. (1975). Light and electron microscopic study of Chlamydia trachomatis infection of the uterine cervix. Journal of Infectious Diseases 131, 678-687.

Varma, V. A., Melin, S. A., Adamec, T. A., Dorman, B. H., Siegfried, J. M., Walton, L. A., Carney, C. N., Norton, C. R. \& Kaufman, D. G. (1982). Monolayer culture of human endometrium : methods of culture and identification of cell types. In Vitro 18 , 911-918.

Vesterinen, E. H., Nedrud, J. G., Collier, A. M., Walton, L. A. \& Pagano, J. S. (1980a). Selection and subculture of epithelial cells from human uterine ectocervix. Cancer Research 40, 512-518.

Vesterinen, E. H., Carson, J., Walton, L. A., Collier, A. M., KeSKi-Oja, J., Nedrud, J. G. \& Pagano, J. S. (1980b). Human ectocervical and endocervical epithelial cells in culture: a comparative ultrastructural study. American Journal of Obstetrics and Gynecology 137, 681-686.

WARD, M. E. (1983). Chlamydial classification, development and structure. British Medical Bulletin 39, $109-115$

WeISS, E. \& DRESSLER, H. R. (1960). Centrifugation of rickettsiae and viruses onto cells and its effect on infections. Proceedings of the Society for Experimental Biology and Medicine 103, 691-695.

WYrick, P. B., Brownridge, E. A. \& IVINS, B. E. (1978). Interaction of Chlamydia psittaci with mouse peritoneal macrophages. Infection and Immunity 19, $1061-1067$ 